\title{
Performance and kinetics analysis of an aerobic sequencing batch flexible fibre biofilm reactor for milk processing wastewater treatment
}

Mohamed Abdulgader ${ }^{1}$, Jimmy $\mathrm{Yu}^{1}$, Ali Akbar Zinatizadeh ${ }^{2}, 3$, Philip Williams ${ }^{1}$, Zahra Rahimi ${ }^{2}$

${ }^{1}$ School of Engineering and Built Environment, Griffith University, Nathan Campus, QLD, 4111, Australia.

${ }^{2}$ Environmental Research Center (ERC), Department of Applied Chemistry, Faculty of Chemistry, Razi University, Kermanshah, Iran.

${ }^{3}$ Department of Environmental Sciences, University of South Africa, Pretoria, South Africa. 


\begin{abstract}
In this study, a sequencing batch flexible fibre biofilm reactor (SB-FFBR) is used for efficient and cost-effective treatment of milk processing wastewater (MPW). The SB-FFBR, modified type of a typical sequencing batch reactor (SBR), is made up of eight bundles of flexible fibre as a supporting media for microorganisms'growth. The working volume and the cycle length of the bioreactor are $8 \mathrm{~L}$ and $24 \mathrm{~h}$, respectively. The biological performance of the bioreactor is studied at 10, 3 and 10 various levels of the influent chemical oxygen demand $\left(\mathrm{COD}_{\mathrm{in}} ; 610-8193 \mathrm{mg} \mathrm{L}^{-}\right.$ $\left.{ }^{1}\right)$, retention time (RT; $1,1.6$ and 2 days), and organic loading rate (OLR; 0.38-8.19 $\mathrm{gCOD} \mathrm{m}^{-3} \mathrm{~d}^{-}$ $\left.{ }^{1}\right)$, respectively. From the results, the minimum COD and total suspended solids (TSS) removal efficiency of $86.8 \%$ and $77.3 \%$ were achieved at OLR of $8.2 \mathrm{~kg} \mathrm{COD} \mathrm{m}^{-3} \mathrm{~d}^{-1}, \mathrm{COD}_{\text {in }}$ of $8193 \mathrm{mg}$ $\mathrm{L}^{-1}$ and RT of 1 day. While, an excellent COD and TSS removal efficiency were found to be 97.5 $\%$ and $99.3 \%$, respectively, at low OLR of $0.4 \mathrm{~kg} \mathrm{COD} \mathrm{m}^{-3} \mathrm{~d}^{-1}, \mathrm{COD}_{\text {in }}$ of $945 \mathrm{mg} \mathrm{L}^{-1}$ and RT of 2 days. Furthermore, the kinetic coefficients of COD removal were computed using a first order substrate removal model at different COD concentrations. The first order kinetic constant, (k), was $0.60,0.65$ and $0.357 \mathrm{~h}^{-1}$ for 500,810 and $2000 \mathrm{mg} \mathrm{COD} \mathrm{L}^{-1}$, respectively. The use of the flexible fibre as a packing material provided a huge surface area for more microorganism attachment. Therefore, the results demonstrated the SB-FFBR has acted as a suitable and effective strategy in treatment of milk processing industrial wastewater.
\end{abstract}

Keywords: Biofilm; flexible fibre; milk processing wastewater; COD removal, SB-FFBR 


\section{Introduction}

Nowadays, the milk processing industry has shown a fast growth all over the world. For example, in Australia, this industry is considered as the third largest rural industry which has crucial contribution in the local economy of this country. Generally, the manufacturing process in dairy industries, including milk processing, cleaning, disinfection, heating and cooling, packaging and cleaning of the milk reservoirs, highly relies on consuming a large volume of pure water (with 1 to 10 ratio of water to milk) due to sanitation issues (Qasim and Mane, 2013). Therefore, such industries generate nearly $0.2-10 \mathrm{~L}$ of wastewater per liter of processed milk (Balannec et al., 2005). The dairy wastewater is characterized by high contents of 5-day biological oxygen demand $\left(\mathrm{BOD}_{5}\right)$, chemical oxygen demand (COD) and nutrients, high levels of dissolved and suspended solids and detergents (Andrade et al., 2014; Haynes, 2010; Rahimi et al., 2016; Sarkar et al., 2006). It is noted that a part of COD content of milk processing wastewater (MPW) is slowly biodegradable. Thus, the release of untreated or improperly treated dairy wastewater to the environment causes destructive impacts such as eutrophication phenomenon, oxygen depletion, and ammonia toxicity (Buabeng-Baidoo et al., 2017). In this regard, an efficient treatment approach is urgently required before letting the dairy wastewater free.

Various treatment techniques including physical, chemical, and biological have been employed to remove slowly biodegradable COD (Ghasemi et al., 2016, Birjandi et al., 2013, Pirsaheb et al., 2009). The treatment approaches of dairy wastewater involving mechanical, physicochemical and biological methods are aimed at reducing the organic matters and nutrients as well as minimizing the sludge volume. Considering highly biodegradable characteristic of the dairy wastewater, the biological treatment processes are always preferred as a reliable method for 
remediation of dairy processing wastewaters treatment (Kushwaha et al., 2011; Slavov, 2017). In overall, the aerobic treatment systems can be operated either as suspended growth or as attached growth (biofilm) or combination of both.

Sequence batch reactor (SBR) has extensively been employed to treat wastewater because of simplicity in operation and configuration, high tolerance to various loading shocks, sophisticated performance and effluent flexibility (Asadi, et al. 2012). Abdulgader et al. (2009) reported 96.5 $\%$ COD removal efficiency in a lab scale SBR treating synthetic milk processing wastewater for a period of $18 \mathrm{~h}$ (Abdulgader et al., 2009). Nevertheless, these technologies have been encountered with some serious challenges such as high production of sludge at high organic loading and poor sludge settleability (Eddy, 1991; Sirianuntapiboon et al., 2005). Thus, some researchers have tried to modify SBR to enhance bioreactor performance. For example, Bae et al. developed a membrane coupled sequencing batch reactor (MSBR) to treat dairy wastewater (Bae et al., 2003). The proposed system exhibited a promising performance at OLR of $1.34 \mathrm{~kg} \mathrm{BOD}_{5}$ $\mathrm{m}^{-3} \cdot \mathrm{d}^{-1}$. Asadi et al. have successfully developed SBR via integrating batch and continuous regimes to promote the biological performance in terms of simultaneous removal of carbon, nitrogen, phosphorus (CNP) (Asadi et al., 2016a, 2016b, 2012; Asadi and Ziantizadeh, 2011).

The wastewater treatment through attached-growth (biofilm) systems also have been widely studied by researchers (Lu et al., 2014; Najafpour et al., 2006). Zinatizadeh et al. investigated the performance of a lab-scale sequencing batch biofilm reactor (SBBR) treating a synthetic dairy wastewater (Zinatizadeh et al., 2011). In this research, COD removal efficiency of $99.5 \%$ was attained at incoming COD of $5000 \mathrm{mg} / \mathrm{L}$. Najafpour et al. (2006) studied the performance of a lab-scale rotating biological contactor (RBC) bioreactor in order to treat food canning wastewater (Najafpour et al., 2006). In this research, COD removal percentage was found to be 
about $97 \%$ at OLR of $14.5 \mathrm{~kg} \mathrm{COD} \mathrm{m}^{-3} \mathrm{~d}^{-1}$. In another study, Yu et al. (2003) used a double stage flexible fibre biofilm reactor to purify an effluent from food processing industry (Q. J. Yu et al., 2003). COD removal of $96 \%$ was reported at retention time of $8 \mathrm{~h}$ and OLR of $7.7 \mathrm{~kg} \mathrm{COD} \mathrm{m}^{-}$ ${ }^{3} \cdot \mathrm{d}^{-1}$. In another study, researchers have developed SBR using integrating technologies of SBR, membrane and moving bed bioreactor in a novel bioreactor called sequencing batch moving bed membrane bioreactor (SBMBMBR) (Yang et al., 2010). The author reported COD removal of 93.5 \% at different COD/TN ratios. Abdulgader et al. (2019) fabricated a single stage flexible fibre biofilm reactor (SS-FFBR) to treat milk processing wastewater (MPW) under different COD $_{\text {in }}$ and HRTs (Abdulgader et al., 2019). From the results obtained, the optimum removal efficiency was found at HRT of $8 \mathrm{~h}, \mathrm{COD}_{\text {in }}$ of $3922 \mathrm{mg} \mathrm{L}^{-1}$ and OLR of $11.67 \mathrm{~kg} \mathrm{COD} \mathrm{m}^{-3} \mathrm{~d}^{-1}$. To date, a few studies have been reported regarding the development of SBR using flexible fibre biofilm reactors treating industrial wastewater (Abdulgader et al., 2009; Q. Yu et al., 2003; Q. J. Yu et al., 2003). Abdulgader et al. (2009) developed an innovative integrated sequence batch flexible fibre biofilm reactor (SB-FFBR) by combining SBR and flexible fibre biofilm reactors (Abdulgader et al., 2009). The flexible fibres provided high specific surface area for microorganisms' growth led to increasing biomass concentration. The biological performance of the bioreactor was analysed under different COD concentrations (610, 2041 and $\left.4382 \mathrm{mg} \mathrm{L}^{-1}\right)$ while retention time (RT) was kept constant at 1.6 days. The bioreactor indicated the good capacity in terms of COD removal $(97 \%)$ at OLR of $2.74 \mathrm{~kg} \mathrm{COD} \mathrm{m}^{-3} \mathrm{~d}^{-1}$. Therefore, these reported literatures have motivated us to evaluate the performance of SB-FFBR treating milk processing industrial effluent via extending concentration ranges of COD, RTs and OLR at 10 and 3,10 various levels, respectively, to determine the bioreactor capacity in terms of the COD and total suspended solids (TSS) removal efficiency/rate. The effect of sludge loading rate (SLR) 
on the COD and TSS removal efficiency/rate is studied as well. Moreover, kinetic coefficients and biofilm morphology are studied.

\section{Materials and methods}

\subsection{Source and characterization of wastewater}

Milk processing wastewater (MPW) used in this study was collected from National Food company located in Brisbane, Australia. The raw wastewater was regularly collected from the factory effluent stream and carried directly to the laboratory and kept in a refrigerator at $0-4{ }^{\circ} \mathrm{C}$ to prevent any changes in the wastewater characterization. Table 1 presents the composition of raw wastewater samples.

\subsection{Bioreactor configuration and start-up}

The SB-FFBR used in this study was made from acrylic in a cylindrical shape with diameter of $120 \mathrm{~mm}$ and height of $900 \mathrm{~mm}$, and a total working volume of $8 \mathrm{~L}$. An equalization tank with capacity of $50 \mathrm{~L}$ was used for storage of wastewater and $\mathrm{pH}$ adjustments. Air ceramic porous diffusers were fixed at the reactor bottom for mixing and providing oxygen. Air was supplied to the reactor through the laboratory air tap. Eight bunches of flexible fibre made of rayon fibre were installed in centre of SB-FFBR with the aid of a rope with $885 \mathrm{~mm}$ length as a support frame, to provide packing media for microorganisums'growth. More detailed information concerning fibre specifications and their installation can be found elsewhere (Abdulgader et al., 2009; Q. J. Yu et al., 2003). A peristaltic pump (Cole Parmer, Masterflex, Model 7523-60) was employed to inject the wastewater from storage tank to the top of the SB-FFBR. The excess sludge was discharged from the waste sludge port during the draw period. The schematic diagram of experimental set up is depicted in Fig. S1. Furthermore, detailed information 
regarding the start-up of bioreactor, operation of SB-FFBR, analytical methods, methodology of kinetic analysis and sludge morphology are given in SI.

Table 1. Specifications of raw milk processing effluent.

\begin{tabular}{lc}
\hline Parameters & Concentration $\left(\mathrm{mg} \mathrm{L}^{-1}\right)$ \\
\hline COD & $4000-14250$ \\
BOD & $3000-8910$ \\
$\mathrm{pH}$ & 11.70 \\
Total solids & $5790-6380$ \\
Total suspended solid & $1420-3540$ \\
Volatile suspended solid & $1350-3480$ \\
Total nitrogen (as N) & $\mathrm{N} / \mathrm{A}$ \\
Total phosphate (as P) & 37 \\
Oil and Grease & $\mathrm{N} / \mathrm{A}$ \\
\hline
\end{tabular}

$\mathrm{N} / \mathrm{A}=$ Not analysed

\section{Results and discussion}

\subsection{Performance of SB-FFBR}

The SB-FFBR performance was experimentally investigated by estimating the influence of some process and operational parameters such as $\mathrm{COD}_{\text {in }}$ concentrations, OLR, RTs, and SLR.

\subsubsection{Effect of retention time on the SB-FFBR performance}

Each cycle of the SB-FFBR was operated for a 24 -h period at the three different retention times (1, 1.6, and 2 days) to assess and understand the influence of changes in retention time on the overall reactor performance treating raw milk processing industrial wastewater. The performance of SB-FFBR was studied by estimating the removal efficiency of COD, TSS and turbidity at each cycle. At 1 day retention time, the system was operated for 22 days at a constant influent COD concertation of $8193 \mathrm{mg} \mathrm{COD} \mathrm{L}{ }^{-1}$. The COD removal efficiency of each cycle of operation is plotted as a function of time in Figure 1. The significant variations in COD removal efficiency were observed ranged between 70 to $90 \%$ with an overall average of $86.8 \% \pm 5.2$. From the 
results, a decrease of $30 \%$ in COD removal efficiency took place at the first cycle due to the loading shock during 1 day of operational cycle. But, the COD removal efficiency gradually improved and rose above $70 \%$ when the OLR was as high as $9 \mathrm{~kg} \mathrm{COD} \mathrm{m}^{-3} \mathrm{~d}^{-1}$. The high COD removal efficiency of $86.8 \%$ was obtained at an OLR of $8.2 \mathrm{~kg} \mathrm{COD} \mathrm{m}^{-3} \mathrm{~d}^{-1}$. This confirms that SB-FFBR performance became virtually independent of OLR applied to the system, and relies on the amount of the biomass in the reactor and type of wastewater.

With respect to TSS removal efficiency, the system exhibited wide variations in removal efficiency, $55.5-89.1 \%$ with an overall average of $73 \%$ (Figure 1). The removal efficiency of TSS was not stable during operational cycle. It is evident from the results that the system showed inconsistently and unexpectedly low performance for TSS removal compared with COD removal efficiency. However, good turbidity removal efficiency was shown in Figure 1, and the results were almost stable during the operating time with an overall average of $97.9 \%$. Therefore, it could be stated that system was highly capable of treating wastewater with high OLR under operating conditions. However, the low and variable performance of the SB-FFBR in terms of solids removal efficiency was because of the variations in the solid loading rates (SLR).

The better performance of the reactor was observed when the reactor was operated at RT of 1.6 days. Figure 2a illustrated the COD removal efficiency versus time. The SB-FFBR attained a good level of COD removal, $92.6 \%$, for all influent COD concentrations targeted. Approximately, $97 \%$ of COD removal efficiency was obtained when the system was operated at $610 \mathrm{mg} \mathrm{L}^{-1}$ and $2040 \mathrm{mg} \mathrm{L}^{-1}$ as shown in Figure 2a. These results were quite stable for about 14 days. But, the removal efficiency dropped to $89.3 \%$ as the initial COD concentration rose to $4382 \mathrm{mg} \mathrm{L}^{-1}$. The COD removal efficiency decreased to $87.2 \%$ when influent COD increased to $7636 \mathrm{mg} \mathrm{L}^{-1}$. In this situation, first the reactor displayed a sharp decrease of COD removal 
efficiency, below $61 \%$, which indicates the effectiveness of loading shock on the SB-FFBR performance.

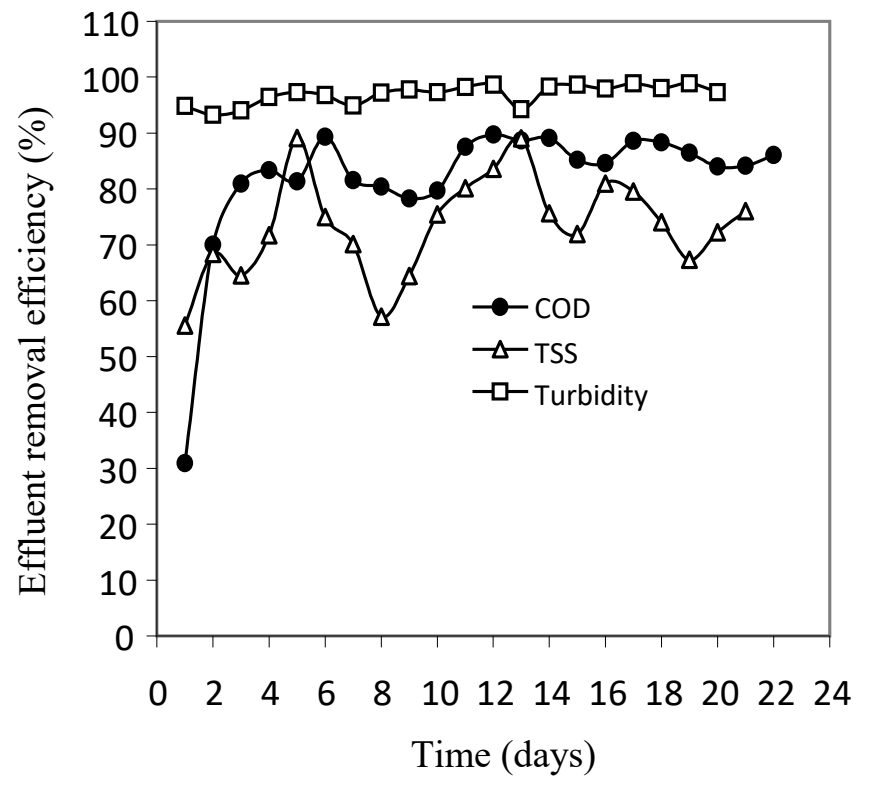

Figure 1. Removal efficiency of COD, TSS and turbidity at RT of 1 day.

In Figure $2 \mathrm{~b}$, it can also be seen that the reactor reached a stable condition in an 8-day cycle. This shows the ability of SB-FFBR to treat industrial wastewater because of the increment in biomass concentration as a result of the presence of high surface area support media. In previous study conducted with a conventional SBR system for treatment of dairy industrial effluent, $90 \%$ COD removal efficiency was achieved at low COD concentration ranged from 400-2500 $\mathrm{mg} \mathrm{L}^{-1}$ (Bandpi and Bazari, 2004). However, with the increase of the retention time to 2 days, enhancement in the reactor performance was noticeable. Figure $2 \mathrm{~b}$ presents the COD removal efficiency of SB-FFBR versus time at retention time of 2 days for different $\mathrm{COD}_{\text {in }}$ concentrations. The SB-FFBR achieved different COD removal efficiency depended on the applied influent COD. A high COD removal efficiency was obtained for all COD concentrations 
employed in the system. The COD removal efficiency was above $97 \%$ when the reactor was run at 945,1913 and $3450 \mathrm{mg} \mathrm{COD}_{\text {in }} \mathrm{L}^{-1}$ correspond to $0.47,0.96$, and $1.72 \mathrm{~kg} \mathrm{COD} \mathrm{m}^{-3} \mathrm{~d}^{-1}$ of OLR, respectively. However, with an increase in the COD amount to $5450 \mathrm{mg} \mathrm{L}^{-1}$ (OLR of $2.72 \mathrm{~kg}$ COD $\mathrm{m}^{-3} \mathrm{~d}^{-1}$ ), COD removal was reported to be $95.5 \%$. In this part of the experiments, the reactor COD removal efficiency quietly varied and did not show any stabilization until after 14 days of operation. The SB-FFBR achieved $94.9 \%$ of COD removal when the system was operated at $8051 \mathrm{mg} \mathrm{L}^{-1}$, corresponding to $4.02 \mathrm{~kg} \mathrm{COD} \mathrm{m}^{-3} \mathrm{~d}^{-1}$ OLR. It is noted that the reactor reached stability approximately after 5 days of operation. Despite the low removal efficiency in the first days of the experiment, attributed to the increment in the influent concentration, the overall performance was good, and the efficiency of COD removal gradually increased. It is obvious that the SB-FFBR can tolerate high OLR at this retention time and can treat wastewater with a very high quality. 


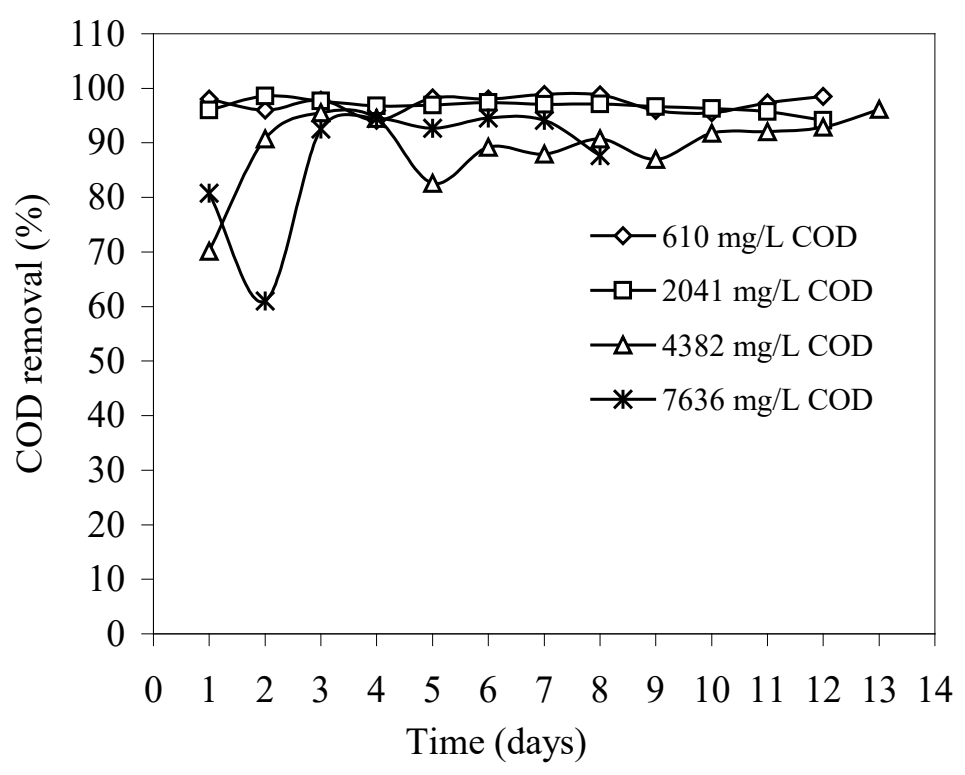

(a)

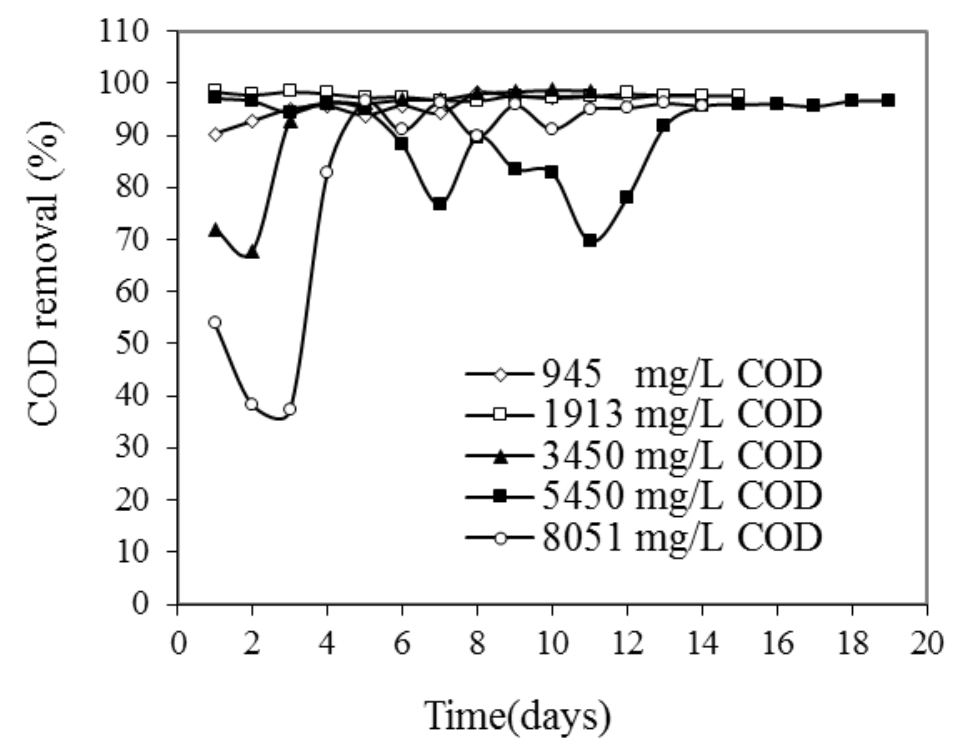

(b)

Figure 2. COD removal efficiencies at RT of (a) 1.6 days; (b) 2 days.

The results of the effluent quality parameters obtained at different retention times $(1,1.6$ and 2 days) after getting stability are summarized in Table 2 . The reactor achieved removal efficiencies of $86.8,77.3$, and $97.8 \%$ in terms of COD, TSS and turbidity removal, respectively, at RT of 1 day and the highest OLR of $8.2 \mathrm{~kg} \mathrm{COD} \mathrm{m}^{-3} \mathrm{~d}^{-1}$. High COD removal was also obtained from previous studies using a continuous two stage flexible fibre reactor (Q. J. Yu et al., 2003). The 
increased amount of biomass concentration inside the reactor was a key factor for achieving high COD removal efficiency at the highest OLR. This was ascribed to the presence of the packing media providing more specific surface area for microorganisms'growth. The total biomass concentration is estimated to be $6970 \mathrm{mg} \mathrm{VSS} \mathrm{L}^{-1}$, comprised of $5000 \mathrm{mg} \mathrm{VSS} \mathrm{L}^{-1}$ of attached biomass and $1970 \mathrm{mg}$ VSS L ${ }^{-1}$ of suspended biomass. The food to microorganism ratio (F/M) can indicate the degree of starvation of the microorganism. In this system, at OLR of $8.19 \mathrm{~kg}$ COD $\mathrm{m}^{-3} \mathrm{~d}^{-1}$, the $\mathrm{F} / \mathrm{M}$ was found to be 1.17. This means there is excess food and the microorganisms may be in the exponential growth phase. In this condition, all substrates were not utilized by the microorganisms and the unconsumed substrate would be discharged into the effluent.

Table 2. SB-FFBR effluent quality.

\begin{tabular}{|c|c|c|c|c|c|c|}
\hline \multirow{2}{*}{$\begin{array}{l}\text { RT } \\
\text { (day) }\end{array}$} & \multirow{2}{*}{$\begin{array}{l}\text { Influent COD } \\
\left(m g \text { CODin } L^{-1}\right)\end{array}$} & \multicolumn{5}{|c|}{ Effluent characteristics } \\
\hline & & $\begin{array}{c}\mathrm{COD} \\
\left(\mathrm{mg} \mathrm{L}^{-1}\right)\end{array}$ & $\begin{array}{c}\text { TSS } \\
\left(\mathrm{mg} \mathrm{L}^{-1}\right)\end{array}$ & $\begin{array}{c}\text { DO } \\
\left(\mathrm{mg} \mathrm{L}^{-1}\right)\end{array}$ & $\mathrm{pH}$ & $\begin{array}{c}\text { Turbidity } \\
\text { (NTU) }\end{array}$ \\
\hline 1 & 8193 & 1077 & 491.6 & 1.04 & 7.5 & 33.1 \\
\hline \multirow{4}{*}{1.6} & 610 & 15.4 & 10 & 5.9 & 6.7 & 1.6 \\
\hline & 2041 & 70 & 2 & 4.55 & 7.1 & 1.93 \\
\hline & 4382 & 460 & 186 & 2.0 & 7.4 & 32.7 \\
\hline & 7636 & 986 & 1030 & 1.8 & 7.3 & 20.3 \\
\hline \multirow{5}{*}{2} & 945 & 23.1 & 2.8 & 3.41 & 6.84 & 1.10 \\
\hline & 1913 & 45.6 & 26.6 & 3.13 & 7.25 & 1.09 \\
\hline & 3450 & 96.7 & 73.3 & 3.53 & 7.55 & 4.17 \\
\hline & 5450 & 255.5 & 85.7 & 2.47 & 7.65 & 17.3 \\
\hline & 8051 & 403.5 & 140 & 1.08 & 7.68 & 10.5 \\
\hline
\end{tabular}


When the reactor was operated at RT of 1.6 days, the amount of $\mathrm{COD}_{\text {in }}$ concentration applied to the reactor showed a substantial influence on the SB-FFBR performance (Table 3). The concentration of dissolved oxygen (DO) in the effluent was declined to nearly $75 \%$ from 5.9 to $1.32 \mathrm{mg} \mathrm{O} \mathrm{L}^{-1}$, which indicates the increase in the activity of biomass as the organic matters concentration rose. The effluent turbidity increased with increment in $\mathrm{COD}_{\text {in }}$ level because of the increase in the solid loading rate (SLR) (Table 1). As the COD in level was increased to 4382 and $7636 \mathrm{mg} \mathrm{L}^{-1}$, the SB-FFBR performance noticeably decreased, where effluent TSS rose to 186 and $1030 \mathrm{mg} \mathrm{L}^{-1}$, respectively. According to the Table 3, the effluent parameters viz. COD eff, turbidity, $\mathrm{pH}$, and TSS, were increased at RT of 2 days. However, the DO concentration decreased with the increase in $\mathrm{COD}_{\text {in }}$ concentration, which is attributed to rise of the microorganism activity. The effluent turbidity showed notable increase as the $\mathrm{COD}_{\text {in }}$ concentration increased that may be because of the increase in the amount of TSS concentration in the reactor effluent. However, the turbidity decreased to $10.5 \mathrm{NTU}$ when the highest $\mathrm{COD}_{\text {in }}$ concentration was applied to the system (8051 $\left.\mathrm{mg} \mathrm{L}^{-1}\right)$. The effluent TSS concentration noticeably increased with the rise in the $\mathrm{COD}_{\text {in }}$ concentration. The lowest TSS, $2.8 \mathrm{mg} \mathrm{L}^{-1}$, was obtained at $945 \mathrm{mg} \mathrm{L}^{-1}$, while it was $140 \mathrm{mg} \mathrm{L}^{-1}$ as the $\mathrm{COD}_{\text {in }}$ was augmented to $8051 \mathrm{mg} \mathrm{L}^{-1}$. In overall, the possible reasons behind these changes were the increase of the solids loading rate (SLR); increment in the biomass growth at such a high OLR and thereby increase in the biomass mass sloughing and washout.

Table 3. Kinetic parameters obtained at different COD concentrations.

\begin{tabular}{cccccc}
\hline COD & $\mathrm{K}$ & $\mathrm{t}_{1 / 2}$ & $\mathrm{C}_{\mathrm{e}}$ & $\mathrm{C}_{\mathrm{o}}$ & \multirow{2}{*}{$\mathrm{R}^{2}$} \\
\cline { 2 - 5 } $\mathrm{mg} \mathrm{L}^{-1}$ & $\mathrm{~h}^{-1}$ & $\mathrm{~h}^{-1}$ & $\mathrm{mg} \mathrm{L}^{-1}$ & $\mathrm{mg} \mathrm{L}^{-1}$ & \\
\hline 500 & 0.606 & 1.14 & 10 & 374 & 0.967 \\
810 & 0.652 & 1.06 & 10 & 510 & 0.999 \\
2000 & 0.357 & 1.94 & 79 & 1402 & 0.955 \\
\hline
\end{tabular}




\subsubsection{Effect of organic loading rate on the SB-FFBR performance}

The influence of OLR on SB-FFBR performance (as COD removal) was evaluated and the results are shown in Figure 3. The study was conducted by increasing the $\mathrm{COD}_{\text {in }}$ concentration at constant retention time (1.6 days). The experimental runs were initiated with low COD concentration of $610 \mathrm{mg} \mathrm{L}^{-1}$ corresponded to $0.4 \mathrm{~kg} \mathrm{COD} \mathrm{m}^{-3} \mathrm{~d}^{-1}$ OLR. As displayed in this Figure, the COD removal percentage exhibited a sharp decrease with increasing organic loading rate. Maximum of $97 \%$ COD removal efficiency was observed. Nonetheless, the COD removal reduced to $87.2 \%$ when OLR rose to $4.77 \mathrm{~kg} \mathrm{COD} \mathrm{m}^{-3} \mathrm{~d}^{-1}$. So, it is predicted that the SB-FFBR can tolerate a OLR more than $4.77 \mathrm{~kg} \mathrm{COD} \mathrm{m}^{-3} \mathrm{~d}^{-1}$ in order to reach a COD removal efficiency of nearly $80 \%$. At $2.74 \mathrm{~kg} \mathrm{COD} \mathrm{m}^{-3} \mathrm{~d}^{-1} \mathrm{OLR}$, the reactor attained $89 \%$ COD removal efficiency. The decrease of COD removal efficiency with increment of OLR may be because of the reduction in contact time between substrates and microorganisms in the SB-FFBR. The removal efficiency of COD reached to $87.2 \%$ at retention time of 1.6 days, this revealed that suspended microorganisms may also significantly contribute in degradation of organic matter. Similar results were observed by research team of Yu et al. (Q. J. Yu et al., 2003). The authors acquired COD removal of $90 \%$ at OLR of $1.04 \mathrm{~kg} \mathrm{COD} \mathrm{m}^{-3} \mathrm{~d}^{-1}$ to treat food processing industrial effluent in a similar system of present work. Also, research team of Sirianuntapilboon et al. attained 89.3 \% COD removal at OLR of $1.340 \mathrm{~kg} \mathrm{BOD}_{5} \mathrm{~m}^{-3} \mathrm{~d}^{-1}$ (Sirianuntapiboon et al., 2005). While, $97.4 \%$ of COD removal efficiency was gained in a rotating biological contactor (RBC) at a substrate loading of $18.44 \mathrm{~g} \mathrm{~m}^{-2} \mathrm{~d}^{-1}$, demonstrating quite high removal rate in such an attached growth system (Najafpour et al., 2006). In this system, the COD removal efficiency declined to $85.4 \%$

since the OLR increased to $36.89 \mathrm{~g} \mathrm{~m}^{-3} \mathrm{~d}^{-1}$. Raj et al. reported the COD removal percentage of 
$91.4 \%$ at COD concentration of $686 \mathrm{mg} \mathrm{L}^{-1}$ corresponding to hydraulic loading of $5 \mathrm{~m}^{3} \mathrm{~m}^{-2} \mathrm{~d}^{-1}$ (Raj and Murthy, 2008).

In contrast, a different effect of OLR on COD removal rate is presented in Figure $3 \mathrm{~b}$. The COD removal rate exhibited an increasing trend with increasing OLR in the ranges of 0.4 to $4.22 \mathrm{~kg}$ COD m $\mathrm{m}^{-3} \mathrm{~d}^{-1}$. This implies the productivity of the system, in terms of the amount of COD removed from wastewater, was high once the reactor was loaded with a high OLR. It has also been observed from the experiments that air flow rate (AFR) increased by increasing the OLR. These findings are ascribed to an increase in biomass concentration at high OLR led to more consumption of dissolved oxygen (DO). It is apparent from the results obtained that with increment of OLR, the rate of COD removal in the SB-FFBR is rising.

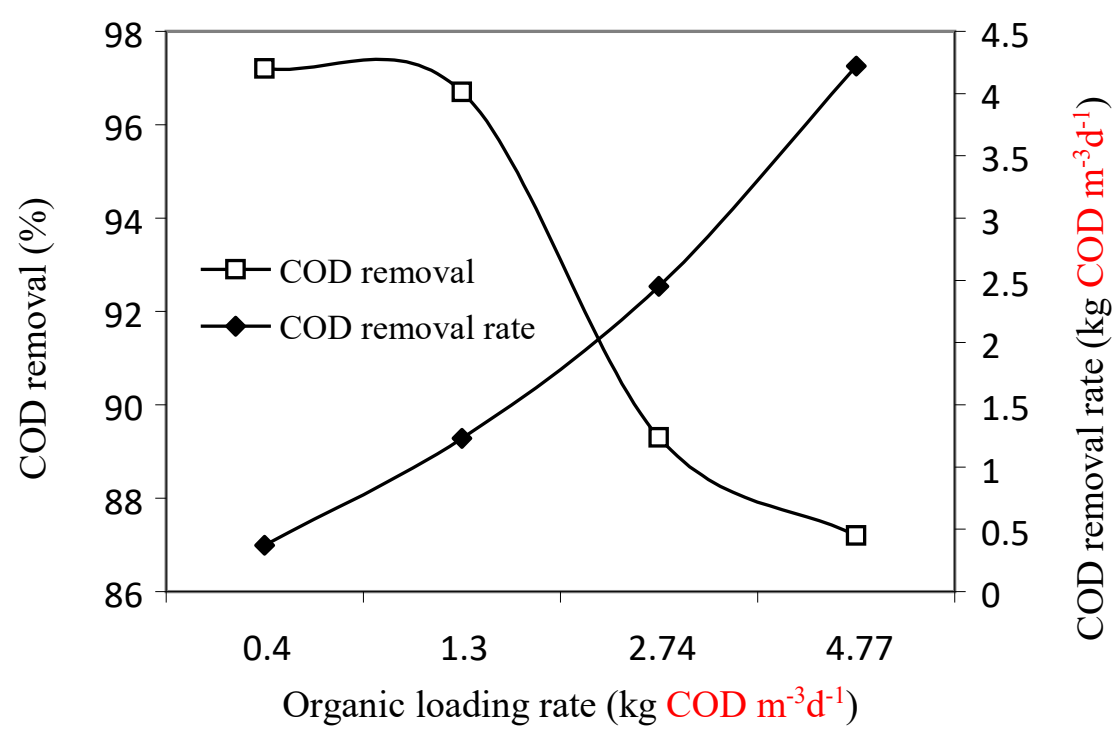

(a) 


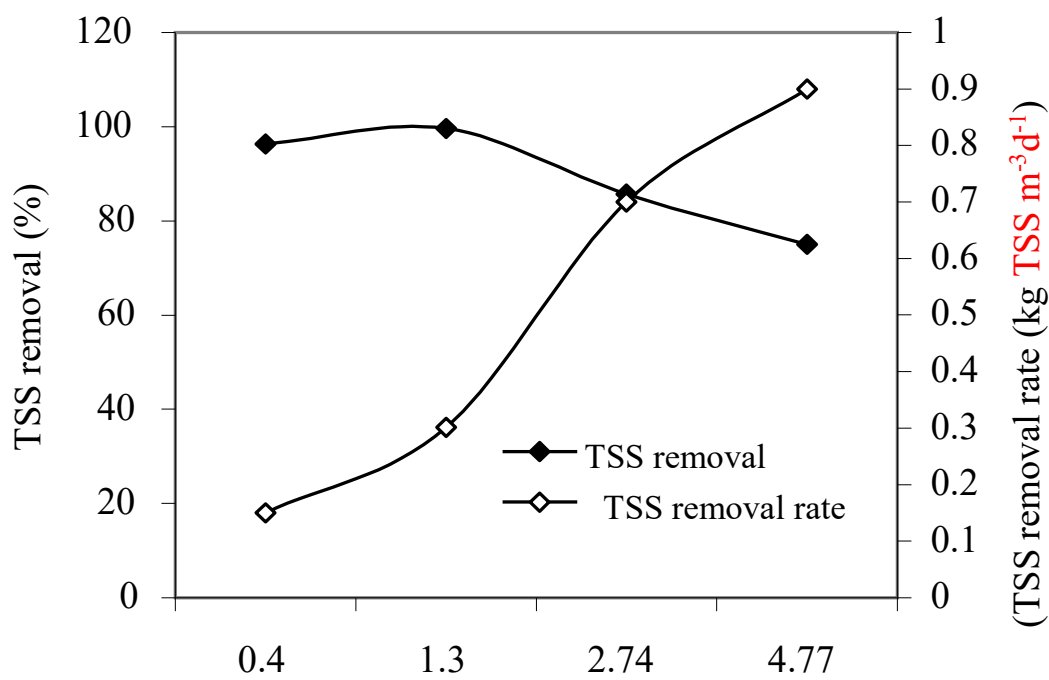

Organic loading rate $\left(\mathrm{kg} \mathrm{COD} \mathrm{m} \mathrm{m}^{-3}\right)$

(b)

Figure 3. The effect of OLR on reactor performance in terms of (a) COD removal and COD removal rate; (b) TSS removal and TSS removal rate (at retention time of 1.6 days).

The effect of OLR on TSS content is shown in Figure 3b. The results showed that the SB-FFBR attained an important decrease in TSS removal with increasing OLR. High TSS removal efficiencies of $96.3 \%$ and $99 \%$ were obtained at low OLRs of 0.4 and $1.27 \mathrm{~kg} \mathrm{COD} \mathrm{m}^{-3} \mathrm{~d}^{-1}$, respectively. Such results may be in the relation with low TSS contents of incoming wastewater. Nevertheless, the increment of OLR to $4.77 \mathrm{~kg} \mathrm{COD} \mathrm{m}^{-3} \mathrm{~d}^{-1}$ resulted in the drop of TSS removal to $75 \%$. The results of this study were in the agreement with study performed by Raj and Murthy (Raj and Murthy, 2008).

On other hand, the performance of the SB-FFBR was also investigated at the retention time of 2 days. The influence of organic loading rate on the SB-FFBR performance is presented in Figure 4. From the Figure 4a, the COD removal dropped by increasing the OLR. The system showed an effective treatability at OLRs of 0.47 and $1.014 \mathrm{~kg} \mathrm{COD} \mathrm{m}^{-3} \mathrm{~d}^{-1}$ with an excellent COD removal efficiency of 97.5 and $97.8 \%$, respectively. Such a high performance was contributed to high biomass concentration attained with increase in the influent COD concentration. The removal 
efficiency started decreasing to $95 \%$ and $94.9 \%$ once the system was loaded with 1.72 and 4.02 $\mathrm{kg}$ COD m $\mathrm{m}^{-3} \mathrm{~d}^{-1}$, respectively. According to the results, it can be inferred the reactor still has capacity to treat high strength wastewater with a OLR more than $4.02 \mathrm{~kg} \mathrm{COD} \mathrm{m}^{-3} \mathrm{~d}^{-1}$ at RT of 2 days. Changes in the COD removal rate at 2 days retention time are presented in Figure 4a. The COD removal rate was augmented almost linearly with the increase in OLR. A similar trend has been stated by Najafpour et al., in a RBC treating seafood wastewater (Najafpour et al., 2005). And also, Yu et al. obtained the similar results using a flexible fibre biofilm reactor for food processing wastewater treatment (Q. Yu et al., 2003).

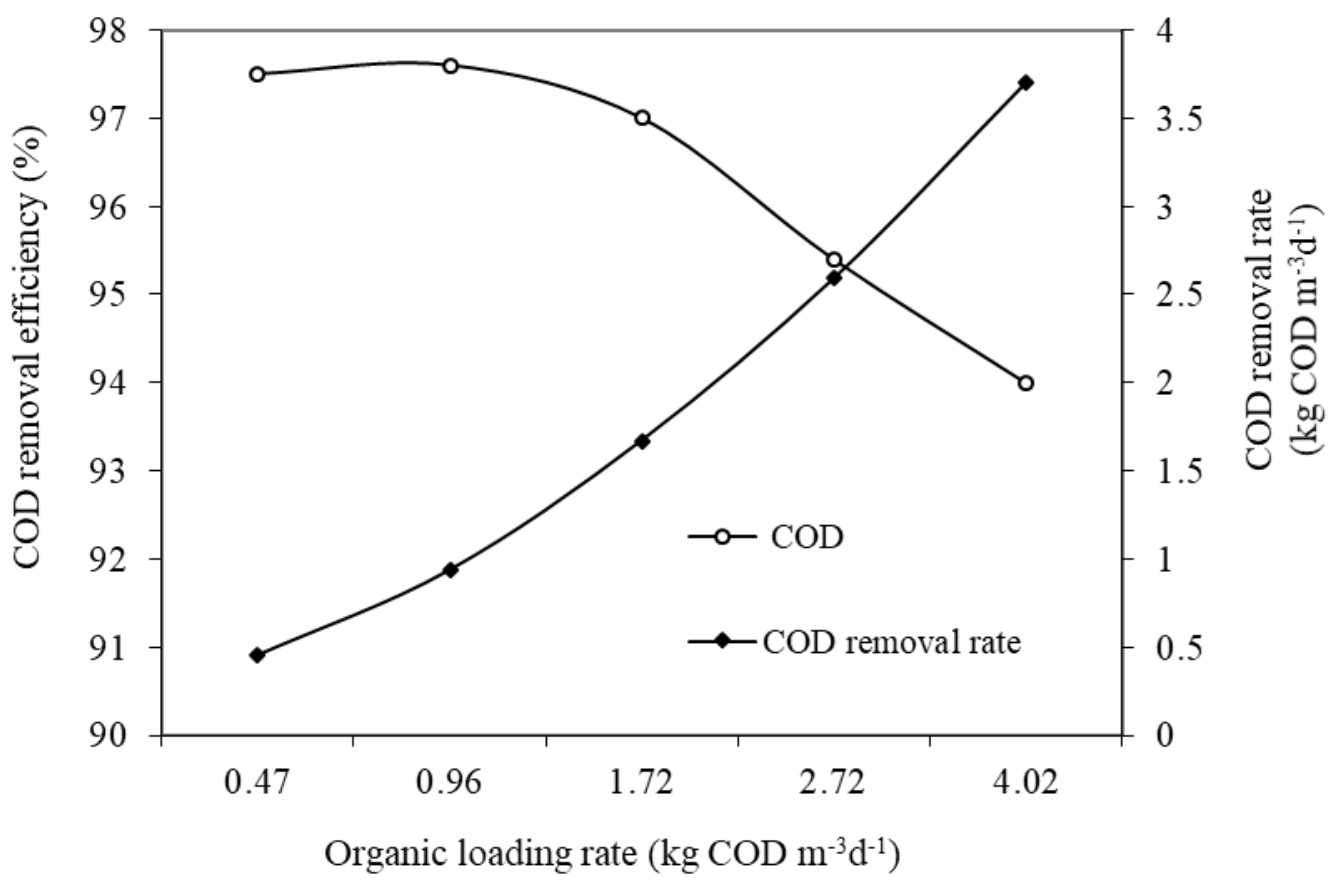

(a) 


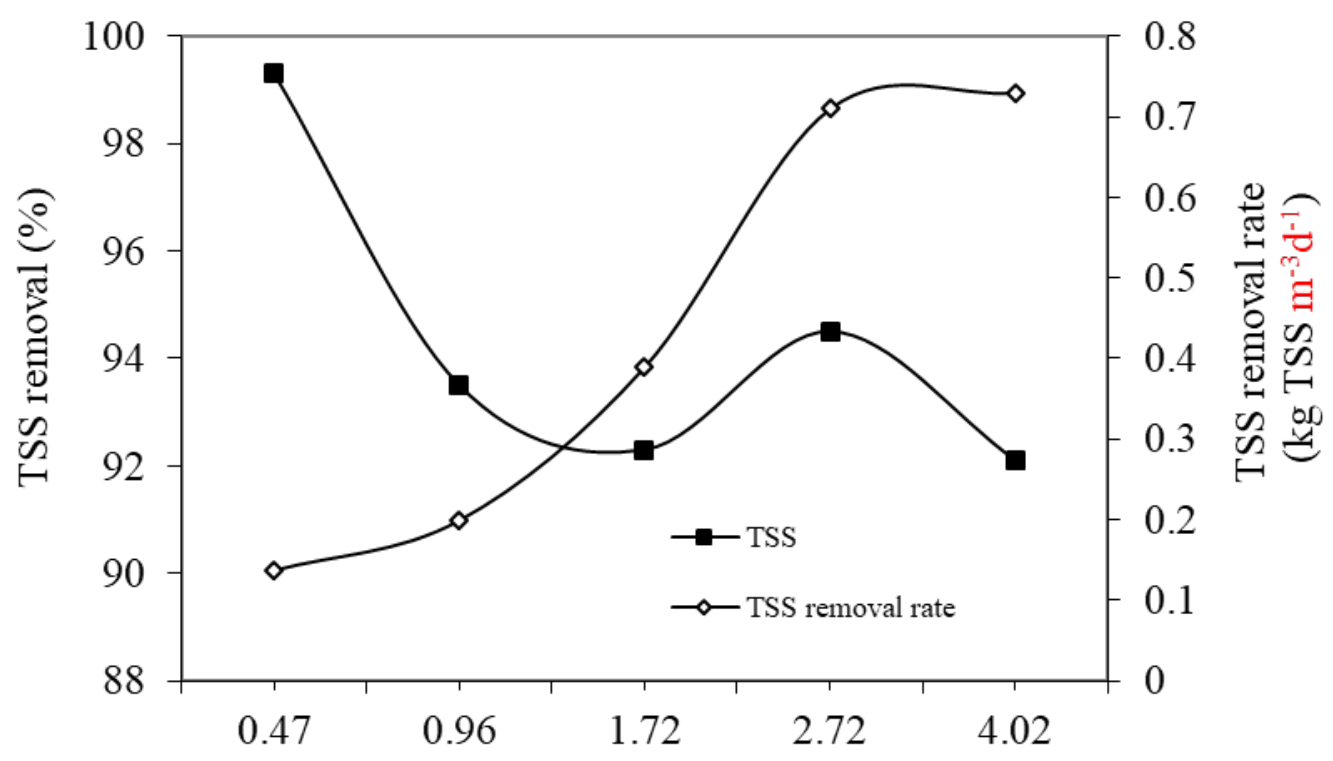

Organic loading rate $\left(\mathrm{kgCOD} \mathrm{m}^{-3} \mathrm{~d}^{-1}\right)$

(b)

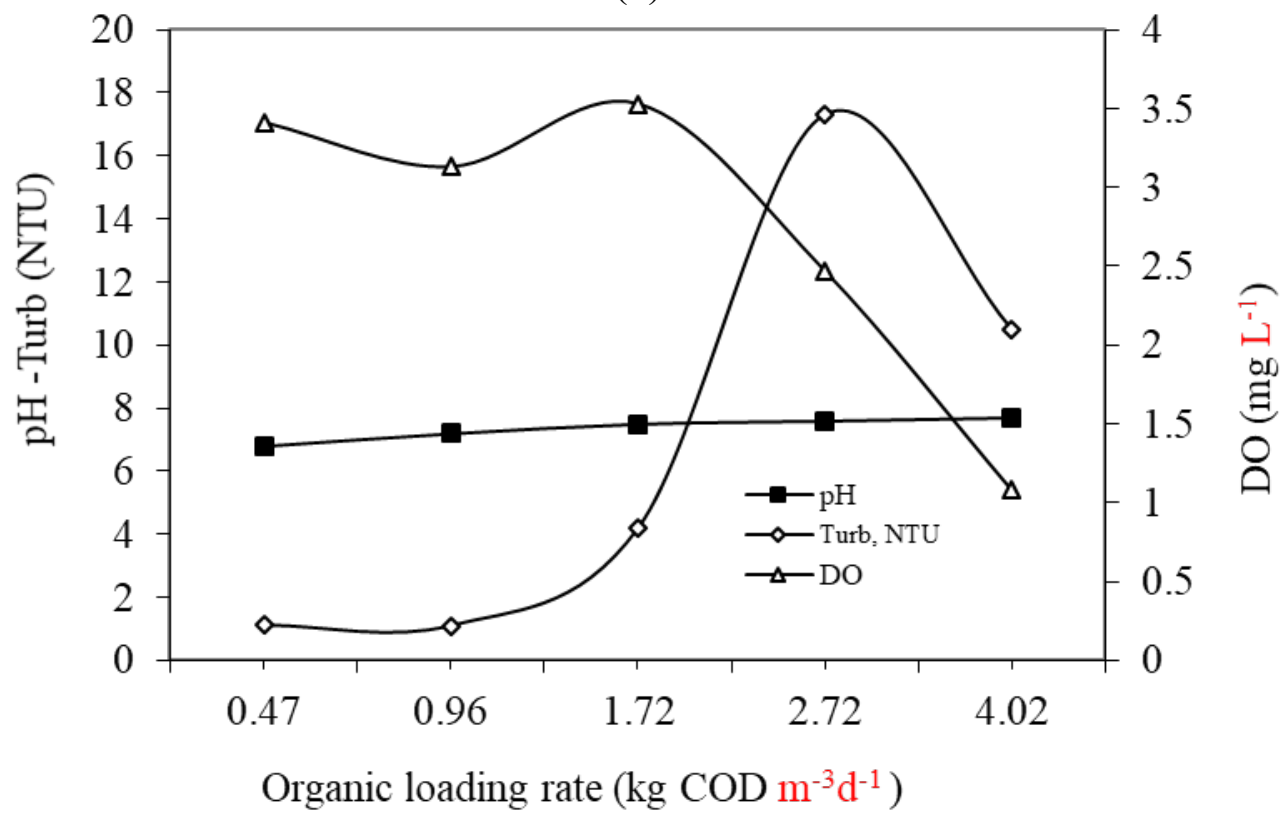

(c)

Figure 4. Reactor performance at RT of 2 days in terms of (a) COD removal and COD removal rate; (b) TSS removal and TSS removal rate; (c) effluent DO, $\mathrm{pH}$ and turbidity.

Figure $4 \mathrm{~b}$ displays the influence of the OLR on the TSS removal efficiency and TSS removal rate. From the Figure $4 b$, the TSS removal efficiency dropped as the OLR increased. TSS removal of $99.3 \%$ was achieved at $0.47 \mathrm{~kg} \mathrm{COD} \mathrm{m}^{-3} \mathrm{~d}^{-1}$ that was mainly due to low amount of solids applied to the system. By increasing the OLR to $0.96 \mathrm{~kg}$ COD m $\mathrm{m}^{-3} \mathrm{~d}^{-1}$, corresponding to 
$0.22 \mathrm{~kg} \mathrm{TSS} \mathrm{m} \mathrm{m}^{-3}, 93.5 \%$ of TSS removal was achieved. The TSS removal efficiency was improved as the OLR was increased to $2.72 \mathrm{~kg}^{\mathrm{COD} \mathrm{m}} \mathrm{m}^{-3} \mathrm{~d}^{-1}$ which may be due to high consumption rate or degradation rate at such long retention time. However, the TSS removal efficiency was deteriorated and decreased to $92.1 \%$, and this was mainly ascribed to an increment in the OLR (4.02 $\left.\mathrm{kg} \mathrm{COD} \mathrm{m}^{-3} \mathrm{~d}^{-1}\right)$ and an increase in the quantity of solids applied to the reactor. Furthermore, Figure $4 \mathrm{~b}$ also illustrates the relation between the OLR and total suspended solids removal rate. The OLR had a more significant influence on the TSS removed from the system. It could be noted that the TSS removal rate increased dramatically when the OLR increased from 0.47 to $2.72 \mathrm{~kg} \mathrm{COD} \mathrm{m}^{-3} \mathrm{~d}^{-1}$. But there was no increasing removal rate at high OLR of $4.02 \mathrm{~kg} \mathrm{COD} \mathrm{m}^{-3} \mathrm{~d}^{-1}$. Totally, the SB-FFBR displayed a good performance on the removal of solids.

Figure $4 \mathrm{c}$ presents the variation in $\mathrm{pH}$, turbidity, and dissolved oxygen (DO) concentration against the OLR. As can be seen from the Figure, the $\mathrm{pH}$ remained practically constant ranged between 6.8 and 7.7 as the OLR increased from 0.47 to $4.02 \mathrm{~kg} \mathrm{COD} \mathrm{m}^{-3} \mathrm{~d}^{-1}$, showing good buffering capacity of the reactor. The OLR also had negative influence on the effluent turbidity (Figure 4c). Increase in OLR gave rise to the increase in the turbidity. However, the SB-FFBR produced a high quality effluent with almost constant level of 1.1 and 1.09 NTU at low OLR of 0.47 and $0.96 \mathrm{~kg} \mathrm{COD} \mathrm{m}^{-3} \mathrm{~d}^{-1}$, respectively. The effluent turbidity was increased to 4.14 and 17.3 NTU when the OLR was increased to 1.72 and $2.72 \mathrm{~kg} \mathrm{COD} \mathrm{m}^{-3} \mathrm{~d}^{-1}$, respectively. Which is attributed to the increase of effluent suspended solids because of loss of biomass or washout out and high SLR. The turbidity of the effluent decreased again to 10.5 NTU once the OLR increased to $4.02 \mathrm{~kg} \mathrm{COD} \mathrm{m}^{-3} \mathrm{~d}^{-1}$. The DO level was nearly stable, above $3 \mathrm{mg} \mathrm{L}^{-1}$, as the OLR 
was augmented from 0.47 to $1.72 \mathrm{~kg} \mathrm{COD} \mathrm{m}^{-3} \mathrm{~d}^{-1}$ (Figure 4c). While, the DO level decreased to 2.47 and $1.08 \mathrm{mg} \mathrm{L}^{-1}$ as the OLR was augmented to 2.72 and $4.02 \mathrm{~kg} \mathrm{COD} \mathrm{m}^{-3} \mathrm{~d}^{-1}$, respectively.

\subsection{Effects of suspended solid loading rate (SLR) on the reactor performance}

The influence of SLR on TSS removal efficiency and TSS removal rate at retention time of 1.6 days is obviously reflected by the results presented in Figure 5. The TSS removal rate relied on the SLR and increased consistently with the increase of SLR. The TSS removal efficiency had no change at SLRs of 0.154 and $0.3 \mathrm{~kg} \mathrm{SS} \mathrm{m}^{-3} \mathrm{~d}^{-1}$. However, it slightly decreased from $85.7 \%$ to $75 \%$ by rising the SLR from 0.81 to $1.19 \mathrm{~kg} \mathrm{SS} \mathrm{m}^{-3} \mathrm{~d}^{-1}$, respectively. It revealed that biodegradation of the suspended solids may require prolonged period. These findings were comparable with those reported in study of Najafpour et al. (Najafpour et al., 2005). They achieved TSS removal efficiency of $88 \%$ at low SLR. El-Kamah also obtained $50 \mathrm{mgL}^{-1}$ of TSS in effluent of activated sludge system with batch regime treating fruit juice industry wastewater (El-Kamah et al., 2010). High TSS removal efficiency points to the reduced quantity of sloughed biomass and the increase of attached biomass on the flexible fibre. In addition, the suspended solids can possibly be adsorbed on the biomass and then broken down the substrates by extracellular enzymes. 


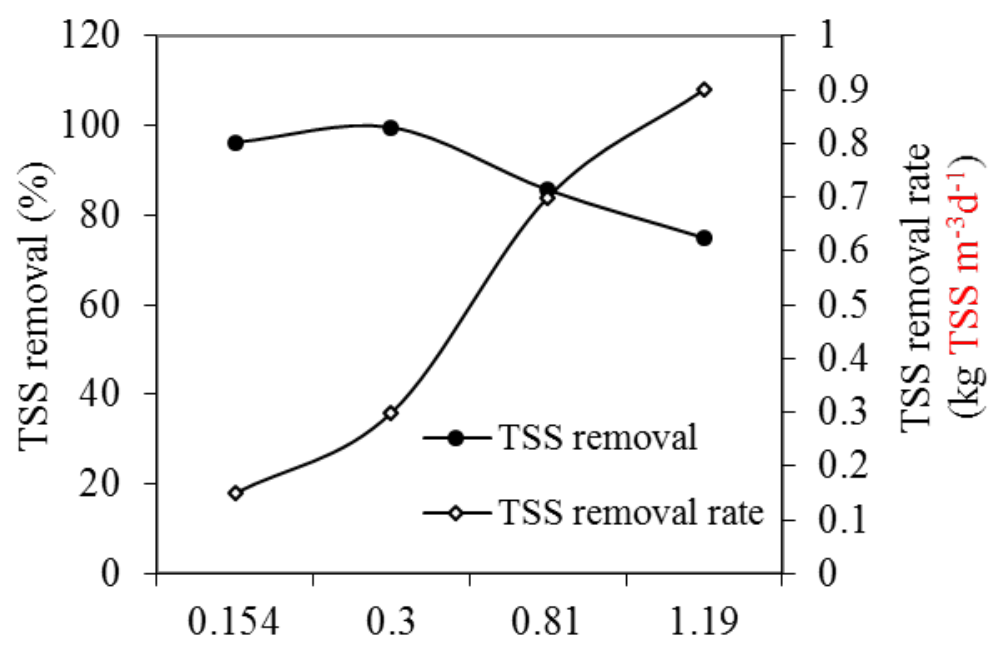

Solid loading rate $\left(\mathrm{kg} \mathrm{SS} \mathrm{m}^{-3} \mathrm{~d}^{-1}\right)$

(a)

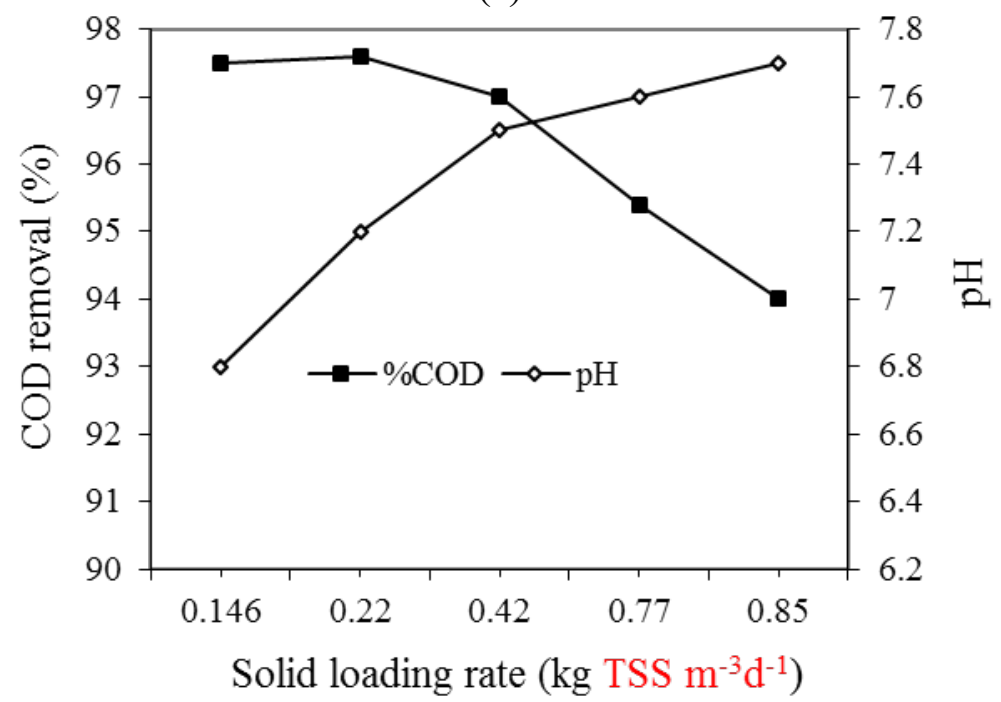

(b) 


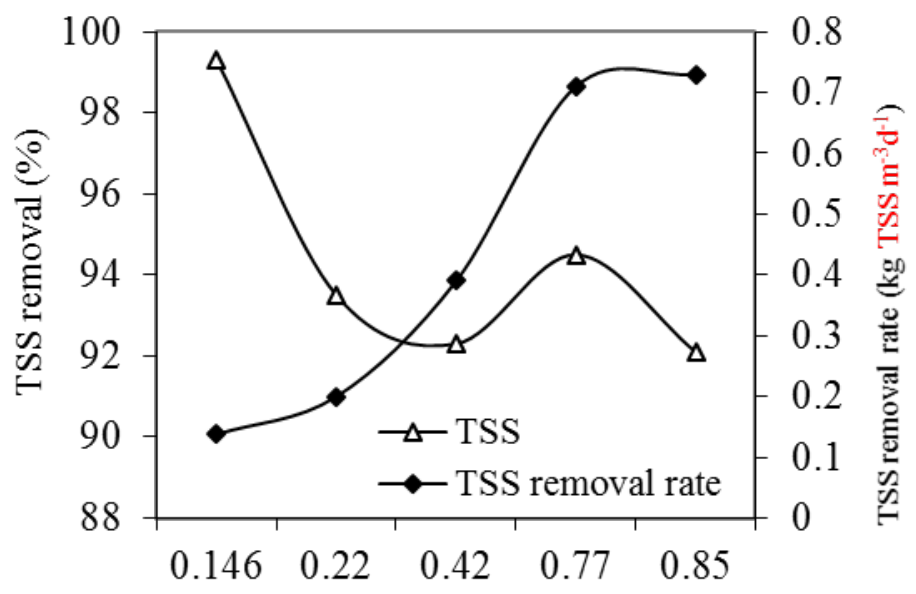

Solid loading rate $\left(\mathrm{kg} \mathrm{TSS} \mathrm{m}^{-3} \mathrm{~d}^{-1}\right)$

(c)

Figure 5. The effect of SLR on (a) TSS removal efficiency and TSS removal rate at RT of 1.6 days, (b) COD removal and $\mathrm{pH}$ at RT of 2 days, (c) TSS removal efficiency and TSS removal rate at $\mathrm{RT}$ of 2 days.

The SB-FFBR was capable of removing COD from high strength wastewater because of high biomass concentration attributed to existing of the flexible fibres. The flexible fibres provide high specific surface area (over $2200 \mathrm{~m}^{2} / \mathrm{m}^{3}$ ) compared to other carrier materials (Raj and Murthy, 2008; Zinatizadeh and Ghaytooli, 2015). The attached biomass on the fibre is prevented to come out from the reactor during withdraw operation of supernatant. Thereby, total biomass concentration and consequently substrate biodegradation are increased.

Figure $5 \mathrm{~b}$ illustrates the relation between $\mathrm{pH}$ and COD removal percentage versus SLR at RT of 2 days. The COD removal efficiency decreased as the SLR increased. The system achieved nearly a constant COD removal of 97.5 and $97.7 \%$ at SLR of 0.146 and $0.22 \mathrm{~kg} \mathrm{TSS} \mathrm{m}^{-3} \mathrm{~d}^{-1}$, respectively. As the SLR was suddenly increased to $0.42 \mathrm{~kg} \mathrm{TSS} \mathrm{m}^{-3} \mathrm{~d}^{-1}$, the removal efficiency of COD slightly dropped to $97 \%$. Nevertheless, the removal efficiency was $94 \%$ at $0.85 \mathrm{~kg}$ TSS $\mathrm{m}^{-3} \mathrm{~d}^{-1}$ of SLR. The effluent $\mathrm{pH}$ was also significantly influenced by the rise of SLR. Tshe $\mathrm{pH}$ gradually increased by increasing the SLR. 
Figure 5c presents the effect of the SLR on the SB-FFBR performance at RT of 2 days. It is clear from this Figure that the increase in the SLR resulted in the decrease in TSS removal efficiency. However, the TSS removal efficiency improved and reached $94.5 \%$ at $0.77 \mathrm{~kg} \mathrm{TSS} \mathrm{m}^{-3} \mathrm{~d}^{-1} \mathrm{SLR}$. Then, the removal efficiency dropped to $92.1 \%$ at the SLR of $0.85 \mathrm{~kg} \mathrm{TSS} \mathrm{m}^{-3} \mathrm{~d}^{-1}$. While the TSS removal rate was increased linearly as the SLR was increased. The TSS removal rates of 0.138 , 0.2 , and $0.39 \mathrm{~kg} \mathrm{TSS} \mathrm{m}^{-3} \mathrm{~d}^{-1}$ were achieved when the system was operated at SLRs of $0.146,0.22$, and $0.42 \mathrm{~kg} \mathrm{TSS} \mathrm{m}^{-3} \mathrm{~d}^{-1}$, respectively. Kinetic analysis and biofilm morphology are discussed in SI.

\section{Conclusions}

The SB-FFBR incorporated with the flexible fibre packing material was successful to achieve a satisfactory performance as COD and TSS removal efficiency. From the results, an inverse relationship was observed between COD removal efficiencies with respect to changes of OLR. While, a direct relationship was reported in the cases of TSS removal efficiency, the COD and TSS removal rates along with changes in OLR. The maximum of COD and TSS removal efficiencies attained at RTs of 2, 1.6 and 1 day(s) corresponded to OLRs of $0.47,0.4$ and $8.19 \mathrm{~kg}$ COD $\mathrm{m}^{-3} \mathrm{~d}^{-1}$ were 97.5 and $99.3 \% ; 97.2$ and $96.3 \% ; 86.8$ and $77.3 \%$, respectively. The kinetic evaluation of the experimental data obtained in the SB-FFBR was carried out using a first order model for substrate removal at different COD concentrations. This model showed a great fitness with having high correlation coefficients $\left(\mathrm{R}^{2}\right)$ ranged from 95 to $99 \%$. The first order kinetic constant, $\mathrm{k}$, was calculated to be $0.60,0.65$ and $0.357 \mathrm{~h}^{-1}$ for 500,810 and $2000 \mathrm{mg} \mathrm{COD} \mathrm{L}^{-1}$, respectively. The results of biofilm morphology showed that the use of the flexible fibre as packing media has provided a massive space for bacteria to grow on, so that it will remarkably 
increase the amount of biomass in the system, $6970 \mathrm{mg} \mathrm{VSS} \mathrm{L}^{-1}$. SEM photos revealed there was no difference in terms of diversity and abundance of species in three flexible fibre bundles. However, a variety of bacteria with different morphologies, rod, coccal, spiral, and helical, were observed in the biofilm. Among these species, flagella and nematode were explored as dominant species. As a final conclusion, the SB-FFBR can be considered as a promising technology to treat high strength wastewaters.

\section{Acknowledgements}

The authors gratefully acknowledge the Griffith University for supporting this research. The authors would like to thank Libyan government for their financial support. In addition, the appreciation also goes to the industry for their excellent cooperation for providing the samples.

\section{References}

Abdulgader, M., Yu, J., Zinatizadeh, A.A., Williams, P., Rahimi, Z., 2019. Process analysis and optimization of single stage flexible fibre biofilm reactor treating milk processing industrial wastewater using response surface methodology (RSM). Chem. Eng. Res. Des. https://doi.org/10.1016/j.cherd.2019.07.011

Abdulgader, M., Yu, Q.J., Zinatizadeh, A.A., Williams, P., 2009. Biological treatment of milk processing wastewater in a sequencing batch flexible fibre biofilm reactor. Asia-Pacific J. Chem. Eng. 4, 698-703. https://doi.org/10.1002/apj.320

Andrade, L.H., Mendes, F.D.S., Espindola, J.C., Amaral, M.C.S., 2014. Nanofiltration as tertiary treatment for the reuse of dairy wastewater treated by membrane bioreactor. Sep. Purif. Technol. 126, 21-29.

Asadi, A., Ziantizadeh, A.A., 2011. Statistical Analysis and Optimization of an Aerobic SBR Treating an Industrial Estate Wastewater Using Response Surface Methodology (RSM). 
Iran. J. Energy Environ. 2 (4), 356-365.

Asadi, A., Zinatizadeh, A.A., Van Loosdrecht, M., 2016a. High rate simultaneous nutrients removal in a single air lift bioreactor with continuous feed and intermittent discharge regime: process optimization and effect of feed characteristics. Chem. Eng. J. 301, 200-209.

Asadi, A., Zinatizadeh, A.A., Van Loosdrecht, M., 2016b. A novel continuous feed and intermittent discharge airlift bioreactor (CFIDAB) for enhanced simultaneous removal of carbon and nutrients from soft drink industrial wastewater. Chem. Eng. J. 292, 13-27.

Asadi, A., Zinatizadeh, A.A., Sumathi, S., 2012. Simultaneous removal of carbon and nutrients from an industrial estate wastewater in a single up-flow aerobic/anoxic sludge bed (UAASB) bioreactor. Water Res. 46, 4587-4598.

Bae, T.H., Han, S.S., Tak, T.M., 2003. Membrane sequencing batch reactor system for the treatment of dairy industry wastewater. Process Biochem. https://doi.org/10.1016/S00329592(03)00063-3

Balannec, B., Vourch, M., Rabiller-Baudry, M., Chaufer, B., 2005. Comparative study of different nanofiltration and reverse osmosis membranes for dairy effluent treatment by dead-end filtration. Sep. Purif. Technol. 42, 195-200. https://doi.org/https://doi.org/10.1016/j.seppur.2004.07.013

Bandpi, M.A., Bazari, H., 2004. Biological Treatment of Dairy Wastewater by Sequencing Batch Reactor. Iran. J. Environ. Heal. Sci. Eng. 1.

Buabeng-Baidoo, E., Mafukidze, N., Pal, J., Tiwari, S., Srinivasan, B., Majozi, T., Srinivasan, R., 2017. Study of water reuse opportunities in a large-scale milk processing plant through process integration. Chem. Eng. Res. Des. https://doi.org/10.1016/j.cherd.2017.02.031

Droste, R.L., 1997. Theory and practice of water and wastewater treatment. J. Wiley, New York.

Eddy, M.\&, 1991. Wastewater Engineering: Treatment Disposal Reuse . McGraw- Hill, Singapore.

El-Kamah, H., Tawfik, A., Mahmoud, M., Abdel-Halim, H., 2010. Treatment of high strength wastewater from fruit juice industry using integrated anaerobic/aerobic system. 
Desalination. https://doi.org/10.1016/j.desal.2009.11.013

Haynes, Y.-Y.L. and R.J., 2010. Long-term Irrigation with Dairy Factory Wastewater Influences Soil Quality. World Acad. Sci. Eng. Technol. 4, 10-23.

Kushwaha, J.P., Srivastava, V.C., Mall, I.D., 2011. An Overview of Various Technologies for the Treatment of Dairy Wastewaters. Crit. Rev. Food Sci. Nutr. 51, 442-452. https://doi.org/10.1080/10408391003663879

Lazarova, V., Manem, J., 1995. Biofilm Characterization and activity analysis in water and waste-water treatment. Water Res. 29, 2227-2245.

Lu, J., Yan, X., Ma, Y., Tian, C., Ding, J., 2014. Impact of salinity on treatment of saline wastewater by sequencing batch biofilm reactor process. J. Cent. South Univ. 21, 19891994. https://doi.org/10.1007/s11771-014-2147-5

Najafpour, G., Yieng, H.A., Younesi, H., Zinatizadeh, A.A., 2005. Effect of organic loading on performance of rotating biological contactors using Palm Oil Mill effluents. Process Biochem. 40, 2879-2884. https://doi.org/10.1016/j.procbio.2005.01.002

Najafpour, G.D., Zinatizadeh, A.A., Lee, L.K., 2006. Performance of a three-stage aerobic RBC reactor in food canning wastewater treatment. Biochem. Eng. J. 30, 297-302. https://doi.org/10.1016/j.bej.2006.05.013

Qasim, W., Mane, A. V, 2013. Characterization and treatment of selected food industrial effluents by coagulation and adsorption techniques. Water Resour. Ind. 4, 1-12. https://doi.org/https://doi.org/10.1016/j.wri.2013.09.005

Rahimi, Z., Zinatizadeh, A.A., Zinadini, S., 2016. Milk processing wastewater treatment in a bioreactor followed by an antifouling O-carboxymethyl chitosan modified Fe3O4/PVDF ultrafiltration membrane. J. Ind. Eng. Chem. 38, 103-112.

Raj, S.A., Murthy, D.V.., 2008. Synthetic dairy wastewater treatment using cross flow medium trickling filter. J. Environ. Sci. Heal. Part A. https://doi.org/10.1080/10934529909376841

Sarkar, B., Chakrabarti, P.P., Vijaykumar, A., Kale, V., 2006. Wastewater treatment in dairy industries - possibility of reuse. Desalination 195, 141-152. 
https://doi.org/https://doi.org/10.1016/j.desal.2005.11.015

Sirianuntapiboon, S., Jeeyachok, N., Larplai, R., 2005. Sequencing batch reactor biofilm system for treatment of milk industry wastewater. J. Environ. Manage. 76, 177-183. https://doi.org/10.1016/j.jenvman.2005.01.018

Slavov, A.K., 2017. General Characteristics and Treatment Possibilities of Dairy Wastewater - A Review. FOOD Technol. Biotechnol. 55, 14-28. https://doi.org/10.17113/ftb.55.01.17.4520

Yang, S., Yang, F., Fu, Z., Wang, T., Lei, R., 2010. Simultaneous nitrogen and phosphorus removal by a novel sequencing batch moving bed membrane bioreactor for wastewater treatment. J. Hazard. Mater. 175, 551-557.

Yu, Q., Xu, H., Williams, P., 2003. Development of flexible fibre biofilm reactor for treatment of food processing wastewater. Environ. Technol. (United Kingdom). https://doi.org/10.1080/09593330309385577

Yu, Q.J., Xu, H., Yao, D., Williams, P., 2003. Development of a two-stage flexible fibre biofilm reactor for treatment of food processing wastewater. Water Sci. Technol. 47, 189-194. https://doi.org/10.2166/wst.2003.0604

Zinatizadeh, A.A., Ghaytooli, E., 2015. Simultaneous nitrogen and carbon removal from wastewater at different operating conditions in a moving bed biofilm reactor (MBBR): Process modeling and optimization. J. Taiwan Inst. Chem. Eng. 53, 98-111. https://doi.org/10.1016/j.jtice.2015.02.034

Zinatizadeh, A.A., Mansouri, Y., Akhbari, A., Pashaei S, 2011. Biological treatment of a synthetic dairy wastewater in a sequencing batch biofilm reactor: Statistical modeling using optimization using response surface methodology. Chem. Ind. Chem. Eng. Q. 17, 485-495. https://doi.org/10.2298/CICEQ110524034Z 